\section{ROSARIO DE ACUÑA Y ÁNGELES LÓPEZ DE AYALA: ESCRITURA Y PACTOS CONTRA EL DOGMA}

\author{
Ana María Díaz Marcos \\ Universidad de Connecticut \\ ORCID iD: https://orcid.org/0000-0003-4509-9369 \\ ana_maria.marcos@uconn.edu \\ Helena Establier Pérez \\ Universidad de Alicante \\ ORCID iD: https://orcid.org/0000-0001-6503-367X \\ Helena.Establier@ua.es
}

Cómo citar este artículo/Citation: Díaz Marcos, A. M. y Establier Pérez, H. (2020). Rosario de Acuña y Ángeles López de Ayala: escritura y pactos contra el dogma. Arbor, 196 (796): a549. https://doi.org/10.3989/arbor.2020.796n2002

Recibido: 26 mayo 2018. Aceptado: 23 octubre 2019.

RESUMEN: Este trabajo aborda el pacto librepensador suscrito por las autoras Rosario de Acuña y Ángeles López de Ayala. Se examinan sus contribuciones en la prensa librepensadora y su activismo feminista a través de un análisis de sus colaboraciones en Las dominicales del librepensamiento, El gladiador: órgano de la "Sociedad progresiva femenina" y El gladiador del librepensamiento. La ideología de estas publicaciones les permitió vincular la lucha feminista con la agenda política de ideología progresista. Se parte de dos ejes complementarios cuya intersección permite abordar su pacto de compromiso y transgresión: la lucha por la igualdad social y por la igualdad de género. Se estudian sus reflexiones sobre la explotación del pueblo por las castas, el empoderamiento de la mujer como agente constructor del progreso y la denuncia vehemente de su sometimiento. Se concluye que los escritos de Acuña y Ayala evidencian con el paso de los años una radicalización que propicia una postura cada vez más trasgresora y un feminismo más combativo, reflejando así su descontento con la actitud paternalista u hostil del librepensamiento y el republicanismo masculino en lo que respecta a los derechos de la mujer.

PALABRAS CLAVE: Feminismo; librepensamiento; compromiso; transgresión; género; laicismo; anticlericalismo; prensa; activismo.

\section{ROSARIO DE ACUÑA AND ÁNGELES LÓPEZ DE AYALA: WRITING AND PACTS AGAINST DOGMA}

Copyright: (C) 2020 CSIC. Este es un artículo de acceso abierto distribuido bajo los términos de la licencia de uso y distribución Creative Commons Reconocimiento 4.0 Internacional (CC BY 4.0).

ABSTRACT: This essay studies the freethinking pact signed by Spanish writers Rosario de Acuña and Ángeles López de Ayala. Their contributions to the freethinking press and their feminist activism are examined through analysis of their collaborations in the publications Las dominicales del librepensamiento, EI gladiador: órgano de la "Sociedad progresiva femenina", and EI gladiador del librepensamiento. The ideology of these publications allowed them to connect their feminism to the political agenda of progressive thought. Two complementary axes are taken into consideration, as this intersection illuminates their pact on commitment and transgression: the fights for social and gender equality. The article explores their thoughts about the exploitation of workers by the castes, the empowerment of women as agents of progress and strong condemnation of their subjugation. In conclusion, their writings show a progressive radicalization that informs a combative feminist approach that reflected their discontent with the paternalist or hostile attitude of patriarchal freethinking and male republicanism on the topic of women's rights.

KEYWORDS: Feminism; freethinking; commitment; transgression; gender; laicism; anticlericalism; press; activism. 


\section{UN PACTO DE COMPROMISO Y TRANSGRESIÓN ENTRE MUJERES: VIVIR Y MORIR POR LA LIBERTAD DE CONCIENCIA}

En torno a los últimos años del siglo XIX y los primeros del XX, las librepensadoras españolas desarrollaron su labor intelectual y cívica en el marco de una activa "cultura del compromiso" (Ramos Palomo, 1999; Ramos Palomo, 2002; Ramos Palomo, 2005) que reúne los nombres de Rosario de Acuña y de Ángeles López de Ayala con los de Belén Sárraga, Amalia Domingo, Ana y Amalia Carvia, María Marín, Soledad Areales, Consuelo Álvarez Pool (Violeta) e incluso, algo más tarde, también el de Carmen de Burgos (Colombine). Aun cuando sus perfiles ideológicos lucieran matices variados (masonas, espiritistas, racionalistas, agnósticas, simpatizantes republicanas, republicanas radicales, filoanarquistas, etc.), el sustrato del proyecto colectivo en el que se imbricaron -una sociedad más libre y más igualitaria, impregnada de conciencia cívica y sustentada por una ética secular-fue un poderoso aglutinador para estas feministas de entre siglos, que se arroparon entre sí en el terreno vital y en el intelectual como estrategia de resistencia y avance, como blindaje ante la arriesgada transgresión que su progresismo feminista representaba en el contexto histórico-social de la España de la Restauración.

Así, su compromiso con un proyecto republicano laico y librepensador encontró su mejor expresión en las redes, las acciones y los espacios de sociabilidad exclusiva o mayoritariamente femeninos, como la prensa, las agrupaciones o las logias dirigidas e impulsadas por mujeres. En esos entornos se implementaron los valores que ayudaban a sustentar y promover su proyecto emancipador: se privilegiaban las voces de mujeres, se reconocía y se elogiaba su autoridad, se incentivaban los lazos y el apoyo mutuo; en definitiva, se impulsaba la solidaridad femenina y se facilitaban las vías para apuntalar un empoderamiento que se les negaba en cualquier otro sector de la vida pública. La colaboración y la sororidad entre mujeres constituyeron así elementos imprescindibles en la dinámica simultánea de compromiso con los ideales librepensadores, por un lado, y de transgresión de los códigos patriarcales, por el otro.

Es precisamente este marco general de alianzas femeninas -en lo privado y en lo público- para la lucha común el que nos permite comprender el estrecho vínculo que une desde la distancia ${ }^{1}$ a Rosario de Acuña (1851-1923) y a Ángeles López de Ayala (1856-1926) durante más de tres décadas. Ambas trabaron amis- tad a finales de los años ochenta en Madrid, ciudad a la que se habían trasladado a principios de la década y donde, tal como atestigua la prensa de la época, tuvieron una intensa -aunque breve- actividad masónica conjunta (Ortiz Albear, 2005, p. 27; Presmanes, 2012, p. 106; Madrid, 1888, 4 de noviembre). También en esos años colaboraron en periódicos comunes, como Las regiones, La luz del porvenir, Las Dominicales del Libre Pensamiento o La Publicidad, y la firma de la escritora madrileña era asidua en la publicación que dirigió López de Ayala entre 1914 y 1920, El Gladiador del Librepensamiento ${ }^{2}$.

No resulta sorprendente que entre ambas se trabaran lazos fecundos y duraderos en la etapa madrileña; pertenecían a la misma generación, eran republicanas, masonas, defensoras a ultranza de la libertad de conciencia y de la igualdad entre los sexos. De hecho, fue probablemente entonces cuando las dos librepensadoras sellaron el pacto recíproco de compromiso y transgresión que rememoraba de este modo Acuña treinta años más tarde:

[...] llegó a mis manos otra [carta] de una mujer que, allá en mi juventud, conocí breves días pero cuya amistad quedó sellada con un pacto recíproco: vivir y morir fuera de todo dogmatismo religioso gastando nuestras energías en despertar alrededor nuestro en cuantos seres pusiera a nuestro lado el destino las ideas racionales de justicia, bondad y belleza, desligadas de todas las religiones dogmáticas. Como este pacto fue hecho por mujeres conscientes, no puede romperse más que con la muerte, pues las almas enteras traen a la vida el caudal que en ella han de verter, sin que manantiales ajenos a la esencia del suyo las enturbien, ni logren desviarlas del cauce que les trazó el destino (Bolado, 20072009, vol. III, pp. 876-877).

Estas frases de Rosario de Acuña pertenecen al discurso que envió a petición de López de Ayala, quien entonces presidía la Sociedad Progresiva Femenina, para que ella misma lo leyera durante la celebración del mitin femenino en la Unión Republicana Radical Graciense el 6 de mayo de 1917 (López de Ayala, 1917, 19 de mayo). Tres años más tarde, Acuña aprovechaba las páginas de El Motín para reivindicar la infatigable lucha de su amiga contra la "fanática religiosidad española" (Acuña, 1920, 17 de abril). En 1923, tras la muerte de Rosario de Acuña, López de Ayala incidía en el mismo periódico en su bondad y su sentido de la justicia, alababa la integridad de su pluma y destacaba su actitud transgresora en materia religiosa (López de Ayala, 1923, 19 de mayo). 
Este pacto personal, de amistad, colaboración y apoyo que Acuña y López de Ayala mantuvieron a lo largo de sus vidas, se tradujo también en un acuerdo ideológico que determinó respuestas desde el compromiso y la transgresión. Como intelectuales y activistas se volcaron en una lucha contra el dogmatismo religioso que requería la propaganda activa de ideales librepensadores -asociados a los conceptos de justicia, bondad y belleza- y aspiraron a la destrucción radical del orden coetáneo para construir un mundo nuevo cuyos pilares se apoyaban en ideales fraternales, racionalistas e igualitarios. El trabajo intelectual de Ángeles López de Ayala y de Rosario de Acuña suponía una contribución a la acción política y social, firmes en su convencimiento de que la humanidad debía esforzarse en la tarea de derribar el edificio del sistema para "levantar sobre las pestíferas ruinas del pasado el templo de lo venidero" (Bolado, 2007-2009, vol. II, p. 1177). El pensamiento y la militancia de ambas estuvieron siempre marcados por el convencimiento de que ese cambio radical nunca podría lograrse sin la acción y el compromiso entusiasta de las mujeres, de forma que su pensamiento feminista constituye el cimiento esencial de su ideario y su proyecto político y social.

En este sentido es posible establecer dos ejes complementarios cuya intersección nos permitirá abordar el estudio del citado pacto de compromiso y de transgresión en ambas autoras. El primer eje gira en torno al concepto de igualdad social, que documenta la presión de las clases sociales y castas dominantes que buscan perpetuar las relaciones de poder atentando contra el derecho natural del individuo a su autodeterminación (Bifani-Richard, 2004, p. 11). El segundo eje tiene que ver con el compromiso y la transgresión feministas y con la lucha por una verdadera igualdad de género, incluso frente a las incoherencias o el paternalismo del propio librepensamiento, del republicanismo o de la izquierda masculina. En este nivel, las relaciones de poder promueven el sometimiento de las mujeres en la cultura patriarcal dominante incluso en entornos supuestamente progresistas. La perspectiva interseccional resulta útil en tanto que permite dar cuenta de la percepción cruzada de esas relaciones de poder (Viveros Vigoya, 2016, p. 2) para rastrear el modo en que el compromiso de estas autoras les permitió denunciar diferentes modos de dominación superponiendo o anteponiendo su propuesta feminista a su proyecto político y social.

Las fuentes elegidas para el seguimiento de la evolución en los fundamentos del compromiso de ambas autoras son tres publicaciones periódicas en las que colaboraron asiduamente. La primera es el semanario racionalista, heterodoxo y anticlerical Las dominicales del librepensamiento, publicado entre 1883 y 1909. Ángeles López de Ayala fundó y dirigió las otras dos publicaciones, portavoces de la ideología librepensadora: El gladiador. Órgano de la Sociedad progresiva femenina (1906-1909) y El gladiador del librepensamiento (1914-1920). El librepensamiento proporcionaba una plataforma legítima desde la que articular el reclamo emancipista y las exigencias igualitarias, y estos periódicos permitían, en principio, vincular la lucha feminista con la agenda política de la ideología progresista (Arkinstall, 2014b, p. 54). Se comprueba, sin embargo, que los escritos de Acuña y de López de Ayala evidencian con el paso de los años una radicalización que da paso a una postura cada vez más transgresora, que les llevó a ejercer un feminismo más combativo en sus escritos, desafiando el statu quo para dar cauce a una visión sumamente crítica de la actitud tibia -cuando no hostil- de muchos hombres, entre los que se incluían los librepensadores o de izquierdas.

\section{ROSARIO DE ACUÑA, APÓSTOL FEMENINO DEL LI- BREPENSAMIENTO}

La extensa producción literaria de Rosario de Acuña abarca casi todos los géneros (teatro, cuentos, ensayos, poemas y lecturas pedagógicas), pero las páginas de los periódicos y seminarios constituyeron el foro predilecto para articular sus ideas más combativas. Su trabajo cultural muestra la vocación de abrir un debate público y promover la construcción de un mundo nuevo utilizando la plana periodística como revulsivo ideológico. Sus artículos y colaboraciones dieron pie a agrias controversias ${ }^{3}$, pero también contó con gran número de lectores y seguidores cautivados por el vigor de su escritura y su compromiso con la causa librepensadora, anticlerical, emancipadora y con los ideales de fraternidad universal propios de la masonería (Lacalzada de Mateo, 2006, p. 31). En 1884 Acuña envía una carta abierta de apasionada adhesión al semanario Las Dominicales del Libre Pensamiento y esta acción supondrá un punto de inflexión en su trayectoria. A partir de entonces la sociedad conservadora y biempensante empezó a considerarla persona non grata, mientras que en las filas progresistas se subrayaba su prestigio intelectual; como evidencia el elogio otorgado por la revista El progreso desde Nueva York ${ }^{4}$ al definirla como "apóstol femenino del librepensamiento".

Hay que subrayar que Acuña provenía de un entorno acomodado, tenía linaje aristocrático y gozaba de cierto prestigio como poetisa y dramaturga dentro de 
los cauces considerados aceptables para una práctica intelectual femenina que se amoldaba a los ideales del decoro, la domesticidad y el neocatolicismo propios de la sociedad isabelina (Sánchez-Llama, 2001, p. 20). La adscripción al librepensamiento marca un hito ${ }^{5}$ en su carrera al iniciarse en ese momento su ardua batalla contra la tiranía, los poderes hegemónicos y la Iglesia católica, que inspiró numerosos textos marcados por una postura desobediente y un anticlericalismo incendiario. Con esta ruptura Acuña se adentraba en terreno pantanoso y su voz iconoclasta levantó ampollas no solo por la beligerancia de su palabra sino porque esta provenía de una mujer a la que no le tembló la mano a la hora de elegir "el camino del polemista que ocupa las columnas tradicionalmente reservadas a los hombres de acción" (Bolado, 2007-2009, vol. I, p. 23). Ese espíritu combativo se interpretó con frecuencia como una transgresión a su género sexual, una "usurpación de los destinos del hombre" (Bolado, 2007-2009, vol. II, p. 1007), por la extendida creencia de que toda empresa crítica que requiriera arrojo era forzosamente viril. La tibia semblanza de la autora que ofrece Cejador y Frauca al narrar la historia literaria de ese período hace referencia a esa militancia que implicaba un doble desacato, de clase y género, al abandonar un espacio intelectual burgués acomodaticio y alejarse de la práctica literaria femenina considerada decorosa para explorar el ámbito menos trillado del activismo político e intelectual: "dio buenas esperanzas con el estreno de su primer drama, mudó de rumbo y se dio a filosofar con escasa suerte [...] sus ideas librepensadoras la hicieron malquista para con casi todos" (Cejador y Frauca, 1918, p. 205).

Acuña entendió su tarea intelectual como una labor de activista comprometida y proletaria de la pluma que trabajaba al lado de sus conciudadanos "como simples obreros en el gran trabajo de los siglos" (Bolado, 2007-2009, vol. IV, p. 175) para trastornar el orden prevalente y construir otro futuro, con la conciencia compartida de hallarse en una encrucijada, ante el "amanecer de una edad nueva que aventará los restos de esta edad presente" (Bolado, 2007-2009, vol. III, p. 844). Para colocar los cimientos de ese proyecto era preciso derribar ancestrales estructuras de poder y soltar lastres religiosos e ideológicos con el fin de establecer un solar limpio sobre el que planificar y construir ese mundo nuevo, llevando a cabo una compleja cartografía de la liberación (Zavala, 2000, p. 120). Esta misión racionalista y anti-hegemónica aspiró a derribar las estructuras arcaicas para edificar nuevos espacios civiles, estableciendo las bases de un futuro utópico más justo, igualitario y fraternal. La pluma fue su herramienta de trabajo, utilizada simultáneamente como piqueta que desmorona y como cincel que labra (París y Zejín, 1889, p. 75), su empeño se apoyaba en la fuerte convicción de que la ideología librepensadora actuaba como una "poderosa palanca que está conmoviendo los cimientos del mundo antiguo" (Domingo Soler, 1976, p. 236) y era, a su vez, inseparable de la lucha por la emancipación de la mujer que constituía la médula del siglo (Bolado, 2007-2009, vol. III, p. 510).

El compromiso feminista se superponía así al librepensador con la certeza de que la pretendida transformación social nunca podría lograrse sin la entusiasta contribución de la mujer. Sus textos exigían que la ciudadana tuviera un papel activo en la regeneración nacional, abogaban por el empoderamiento del sexo y subrayaban la necesidad de una agencia femenina para que la humanidad avanzara hacia ese porvenir habitado por hombres y mujeres conviviendo como compañeros. Acuña desechó la visión dominante de la mujer como sujeto antirrevolucionario y como miembro del sexo retrógrado, otorgando a su modelo de mujer agraria e ilustrada y a la obrera el potencial absoluto para regenerar e impulsar a la humanidad: "sólo en vosotras consiste esa regeneración, ese acomodamiento hacia el progreso en que habrán de crecer los hombres de lo futuro" (Bolado, 2007-2009, vol. I, p. 824). De forma similar denunció las dificultades de la mujer para acceder al conocimiento y los prejuicios con que se juzgaba la actividad femenina en el campo intelectual: "las mujeres que queremos ser personas, solo esto, tenemos que pasar, como cochinillas de circo, por bachilleras, petulantes, histéricas, etcétera" (Bolado, 2007-2009, vol. 4, p. 453). Desde esta postura militante se dirige explícitamente a sus conciudadanas en multitud de textos que destacan la sororidad y el activismo femenino en círculos afines a la masonería, el republicanismo y el librepensamiento:

¡Defender la libertad de pensamiento sin contar con la mujer!, iregenerar la sociedad y afirmar las conquistas de los siglos sin contar con la mujer! ilmposible! [...] ¿No hay mujeres en mi patria? ¿No hay mujeres que piensen lo que pienso y que sienten lo que siento? ¿No hay una pléyade femenina que trabaja heroicamente para el bien de sus hermanas, para la redención de las víctimas? (Bolado, 2007-2009, vol. IV, pp. 152-153)

La protesta contra ese mundo desigual y arcaico se articula sobre dos ejes verticales: por un lado, una red de relaciones de clase desiguales, una visión de castas definida como la "irritante línea que da a unos aquello mismo de que despoja a los otros" (Bolado, 2007- 
2009, vol. II, p. 926) y, por otro, un eje de género que perpetúa la dominación masculina e impide el avance social. El rechazo de ese sistema abusivo y despótico dio pie a una combativa denuncia de las castas que reproducen y refuerzan las injusticias:

[...] fuerzas atávicas en las que renace el espíritu inquisitorial, cruel, sanguinario, de tiempos pasados, fuerzas que son cama caliente de las castas, es decir, de hombres que por la violencia y el castigo se erigen a sí mismos en superiores a los demás hombres y, cuando en una raza, nación, tribu o familia se clava la garra de la casta, sea sacerdotal, científica, capitalista o militar, aquella agrupación de seres humanos que se dejan clavar la garra, está irremisiblemente condenada a desaparecer de entre los seres racionales y quedan todos sus valores deshechos entre las tiranías y las brutalidades (Bolado, 2007-2009, vol. IV, p. 400)

La lucha contra la casta opresora se enuncia paralelamente al compromiso con los "descamisados" (Bolado, 2007-2009, vol. II, 2007, pp. 1055-1078) que constituyen la esperanza de la humanidad y el germen de toda regeneración y por eso mismo serán los pilares de "la nueva era de razón y virtud" (Bolado, 2007-2009, vol. IV, p. 344). Acuña hace referencia repetidas veces a ese vasallaje en el contexto de una visión anti-hegemónica que explora las raíces de la revolución social y clama por los derechos de esa clase oprimida, subrayando la deshumanización de los trabajadores y las violaciones de los derechos humanos motivadas por el afán de lucro y de perpetuación en el poder: "En todas las partes se los aprovecha, se los esquilma, y cuando ya no dan más de sí, se los empuja, y vuelven a los mercados de la miseria a exponer siempre las mismas condiciones" (Bolado, 2007-2009, vol. II, p. 1057). La construcción del porvenir tenía que partir forzosamente de la supresión de esas castas explotadoras que detentaban el poder y sometían al ser humano, siendo la monarquía y el clero los capataces de una maquinaria que aspiraba a reforzar las jerarquías anulando al individuo: "Los reyes y sus similares son la cristalización de la ley de castas, el símbolo del prehistórico pastoreo; los hombres no son ya las piaras, son individualidades aptas para pensar y conocer" (Bolado, 2007-2009, vol. II, p. 1654).

Al subrayar la idea de adocenamiento, Acuña destaca que estas relaciones de poder no se remiten a la explotación económica y moral del individuo sino que la subordinación también lo deshumaniza y aliena. Los ideales del librepensamiento buscaban devolver a la persona su derecho a buscar la verdad por sí misma, a razonar en libertad sin imposición de dogmas ni miedo a la culpa y, por esa razón, una parte crucial de su ata- que a las castas apuntó específicamente a la Iglesia y el clero. Acuña diseccionó los engranajes del poder que operaban dentro de la Iglesia católica retratada como una institución vigilante y opresiva, una fábrica de fieles que imponía el control de la casta sacerdotal sobre el individuo basándose en la supuesta autoridad que le otorgaba su papel de intermediaria entre Dios y el hombre, convirtiendo a los fieles en "rebaño" mediante técnicas que fomentaban la anulación de la voluntad y exigían obediencia (Bolado, 2007-2009, vol. II, p. 926). Las mujeres, consideradas históricamente ciudadanas de segunda fila y eternas menores de edad, tenían una experiencia particularmente singular de este modus operandi (Ramos Palomo, 2011, p. 23-24). La librepensadora fustigó a la casta sacerdotal "opresora, vengativa y cruel" (Bolado, 2007-2009, vol. II, p. 927) que utilizaba el confesionario como trinchera del fanatismo y hacía de la confesión una estrategia para promover la sumisión, apartando al individuo de los afanes terrenales a cambio de promesas de salvación, actuando como fuerza divisoria entre los sexos al interponer al confesor entre los esposos y promover la frialdad en el trato conyugal (Bolado, 2007-2009, vol. II, pp. 937-938). En estas coordenadas se entrecruzaban de nuevo el proyecto librepensador y emancipador, pues Acuña consideraba que el dominio de la Iglesia católica derivaba de su control sobre la vida espiritual de las mujeres, circunstancia que no solo les afectaba a ellas sino que influía en la división de la familia e impedía el progreso de la nación en su conjunto (Bolado, 2007-2009, vol. II, p. 1563).

Es preciso recalcar que el discurso anticlerical de ámbitos progresistas y afines a la cultura política republicana fue muchas veces antifeminista, exhibiendo una actitud de desconfianza y hostigamiento hacia la mujer por su devoción y por su supuesta relación con el clero (Salomón Chéliz, 2011, p. 72), con argumentos que insistían en la necesidad de controlarla restringiendo el tiempo que pasaba en la iglesia o evitando que se confesara. Es notable que numerosos textos presentes en publicaciones que se autodefinían como "revolucionarias" mostrasen mayor preocupación por devolver a la mujer al espacio doméstico que por liberarla de la esclavitud eclesiástica. Se insistía en apartar al sexo devoto del confesionario y de la iglesia, pero muchas republicanas y librepensadoras tuvieron que ser conscientes de la falta de propuestas alternativas a la devoción y las prácticas religiosas que eran también rasgos idiosincrásicos de toda una subcultura femenina, como también sin duda se sintieron desencantadas por el escaso apoyo a las reivindicaciones de las mujeres desde la propia izquierda o el republicanismo "masculino", que las consideró muchas veces la otra mitad reaccionaria: 
La mujer es el espía que el jesuitismo tiene en la familia. A la mujer fanática no hay que fiarle secreto. Más valiera, para la salud moral y espiritual del hombre, que rechazara por sofisticada la mujer más amiga del confesionario que de los deberes maternales. La iglesia ha seducido a la mujer. Ha ocupado la mejor trinchera para combatir al hombre. Y por medio de la mujer consigue que el hombre ceda, que deje de ser revolucionario [...] Deber de todos los que se precien de anticlericales, es, ante todo, librar, apartar, alejar a la mujer de la iglesia, para ligarla a las obligaciones del hogar (Mosén Pedro, 1917, 3 de febrero) ${ }^{6}$.

Acuña consideraba que para construir una España laica y progresista había que liberar a la mujer del yugo de la religión, pero también ofrecerle un papel activo en el proyecto social, dado que el porvenir dependía del ejercicio de la conciencia libre de estas mujeres. Sus textos reflejan una progresiva radicalización en sus planteamientos feministas que responde sin duda a la frustración ante las vacilaciones de muchos correligionarios a la hora de considerar a la mujer como ser pensante, compañera e igual. Convencida de que la tarea de los hombres en esa dirección era ineficaz o tibia, Acuña veía en el activismo femenino el agente supremo para lograr la emancipación de las mujeres: "todo engrandecimiento que le llegue a la mujer en el orden social por determinación del hombre, solo servirá para especificar más claramente su inferioridad [...] Nosotras no debemos esperar nada de nosotras mismas" (Bolado, 2007-2009, vol. III, p. 516).

En sus textos de la última década abundan las referencias a una casta de izquierdas patriarcal, a ese "feminismo de hombres" (Sánchez i Ferré, 2006, p. 119; Ramos Palomo, 2011, p. 28) que mantenía el doble estándar (librepensadores en el foro pero conservadores y católicos en sus casas) y humillaba a las mujeres que militaban en sus filas. Una carta firmada en 1915 pone de manifiesto su desencanto con los hombres de izquierdas y los demócratas que, a pesar de su supuesto "progresismo", seguían avasallando a la mujer:

¡Ah! Nunca me hirieron ni los reaccionarios ni los clericales ni lo conservadores [...] lo que los Ilamados demócratas [...] en los campos de ustedes, en las izquierdas del gorro frigio con la crucecita encima y del chin chin de la libertad con la Inquisición debajo, no han comprendido que las mujeres son personas, siguen todavía dudando si tendrán alma, y se las toma como cosas, como incubadoras, como monigotes de resorte para el placer de la sexualidad [...] "iDios nos libre de las mujeres letradas!", como dijo un pobrecito demócrata en la inauguración de una escuela neutra donde yo acababa de leer un discurso letrado [...] Déjenme... déjenme señores de la izquierda en mi dulce y trabajosa soledad (Bolado, 2007-2009, vol. II, pp. 352-353).

Comprometida con los oprimidos, crítica con las castas y siempre contestataria, Rosario de Acuña evitó asociarse con ideologías y espacios afines al poder o a la élite política y cultural. Estableció para sí un marco flexible de militancia que le permitió una independencia intelectual inédita, fuera de las clasificaciones al uso, actitud que define la postura desobediente e iconoclasta de quien se ubica en el margen del discurso para llevar a cabo su tarea de agitación. Fue una verdadera "terrorista de las ideas" (Zavala, 2004, p. 78) que no aceptó diques a su derecho al pensamiento libre y rehusó siempre adaptarse a los moldes establecidos. Esa heterodoxia le permitió articular un paradigma transgresor que proponía una transformación radical del orden preexistente que pudiera erradicar la desigualdad, y no vaciló a la hora de denunciar las fisuras y contradicciones del librepensamiento y el republicanismo en lo concerniente a la lucha por la emancipación de las mujeres.

\section{3. ÁNGELES LÓPEZ DE AYALA: DEL COMPROMISO LIBREPENSADOR A LA TRANSGRESIÓN FEMINISTA}

La prensa fue, para Ángeles López de Ayala, el medio predilecto a la hora de canalizar el incesante activismo político-social en el que fraguó su sólida vocación librepensadora y republicana. De hecho, durante más de cuatro décadas en las que mantuvo prudente distancia de las rencillas partidistas, las páginas periodísticas le sirvieron para defender, explicar e impulsar los ideales de base del republicanismo español sin ceder ni un ápice en sus arraigadas convicciones ideológicas.

Recién estrenado el siglo XX, en 1901, reconocía haber ya realizado campaña republicana en más de cuarenta publicaciones diferentes (López de Ayala, 1901, 24 de mayo) -en algunas, como Las Dominicales del Libre Pensamiento, con asiduidad asombrosa ${ }^{7}$-, labor a la que se ha de añadir su empeño en la promoción y dirección de cuatro periódicos entre 1896 y 1920: El Progreso, El Gladiador, El Libertador y El Gladiador del Librepensamiento (Arkinstall, 2014a, p. 64). Desde luego, sus colaboraciones en Las Dominicales del Libre Pensamiento y en la serie de los Gladiadores -bien estudiada por M. a Dolores Ramos Palomo (2010)- son las más numerosas y permiten trazar un retrato bastante ajustado de los asuntos de interés prioritario para ella en ese período: la propaganda republicana, la reivindicación social, la batalla por el laicismo, la 
emancipación de las mujeres y, en el sustrato común de todos ellos, la exaltación de la libertad, la justicia, la razón y la igualdad.

Uno de los ejes transversales de ese compromiso por la justicia y por la igualdad en el que Ángeles López de Ayala se empeñó de forma constante en su actividad periodística lo conforman las nociones de casta y de clase. Son muchos los artículos en los que la autora nos ofrece su particular visión de la sociedad española, escindida en dos castas antitéticas e irreconciliables, la de los explotadores y la de los explotados, que a su vez encarnan dos imágenes del poder contrapuestas y habituales en los discursos de la izquierda republicana de entre siglos: un poder restringido, espurio y sectario, que trata de imponerse por la fuerza de los hechos -que no de las razones ni del derecho natural- a otro popular y legítimo.

Las críticas al envilecimiento de las clases superiores de la sociedad monárquica, formuladas en tono ético y cargadas de connotaciones sentimentales, constituían un signo característico, como bien estudió Álvarez Junco (1994, pp. 274-275), de la cultura republicana española del cambio de siglo. Siguiendo este camino, en los textos de López de Ayala pululan los "tiranos", "caciques" y "déspotas", en representación de ese poder impuesto que se perpetúa como tal a costa del sufrimiento y de la opresión políticoeconómica sobre las clases populares, y que únicamente se justifica mediante la existencia de las jerarquías sociales: en su cumbre, el "árbol podrido del caduco régimen monárquico" (López de Ayala, 1895, 22 de febrero), es decir, la corona borbónica, y en los aledaños de aquel, al servicio de los intereses de "la fiera de la reacción triunfante" (López de Ayala, 1908, 1 de febrero), las "huestes negras" (López de Ayala, 1916, 3 de junio), es decir, los gobernantes, los burgueses, los patronos, los fabricantes, las fuerzas del orden, y fundamentalmente los "explotadores del altar" (López de Ayala, 1895, 22 de febrero).

Especialmente cáusticos son los numerosos artículos dedicados durante casi cuatro décadas a arremeter contra los ministros de la Iglesia y demás integrantes de la clerecía nacional, un elemento también clásico en el argumentario de la ideología democrático-republicana de la época (Álvarez Junco, 1990; Álvarez Junco, 1993; Suárez Cortina, 2000). De hecho, en sus escritos de tono anticlerical, la autora no escatima en invectivas, improperios, sátiras y mofas de todo calado: "seres repulsivos", "corazones congelados por el frío soplo de un egoísmo repugnante", "inteligencias atrofiadas a causa de los devo- rantes [sic] efluvios del estómago" (López de Ayala, 1907, 12 de octubre), degenerados, aprovechados, "pandilla de zánganos con extraña indumentaria" (López de Ayala, 1915, 4 de diciembre), feminicidas e infanticidas (López de Ayala, 1915, 17 de abril), etc. Evidentemente, el anticlericalismo, uno de los pilares fundamentales del afán secularizador del librepensamiento español (Gómez Molleda, 1996, pp. 297-320), no sorprende en una ferviente republicana, de convicciones íntimas tan sobrias como las que la autora revela en sus escritos, donde acostumbra a criticar el efecto de las religiones positivas sobre los individuos, mostrándose profundamente refractaria a cualquier género de manifestación u ostentación externa en materia espiritual.

Uno de los aspectos que incomoda especialmente a López de Ayala en la labor espiritual del clero es su capacidad de injerencia en las actitudes y en las conciencias populares. Esta "influencia omnímoda [...] sobre todas las clases de esta mal pergeñada sociedad" le confiere una "soberanía ilimitada" (López de Ayala, 1915, 4 de diciembre) que supone una forma más de opresión ideológica sobre los parias sociales. En este sentido, la autora convierte en foco principal de sus escritos antieclesiásticos la revelación de las alianzas entre las castas dominantes, los poderes fácticos, para asfixiar y explotar permanentemente a quienes ocupan las escalas más bajas de la jerarquía social. El clericalismo es, para López de Ayala, una de las causas de la asimetría social, un problema que requiere ser resuelto para eliminar "el yugo clerical" (López de Ayala, 1894, 7 de diciembre) y "arrancar de nuestro suelo las raíces de la explotación que tras el altar se parapeta" (López de Ayala, 1914, 21 de junio).

Frente a esos perversos pactos tiránicos entre poderes civiles y religiosos, emerge insistentemente en los artículos de López de Ayala la noción de "pueblo" oprimido, custodiado por las castas dominantes en una minoría de edad permanente, ingenuamente encandilado con las promesas de una falsa libertad y de unos derechos fingidos que en realidad tratan de encubrir la esclavitud de la ignorancia. La denuncia de la precaria situación económico-social de las clases trabajadoras (López de Ayala, 1903, 13 de marzo; López de Ayala, 1916, 16 de julio), es una de las constantes de sus artículos, que apuntan a la religión católica como una de los principales responsables en la institución de este injusto sistema de clases sociales consistente en "la humillación de los unos y el triunfo y el despotismo de los otros" (López de Ayala, 1916, 16 de julio). 
La imagen idealizada del pueblo sojuzgado, caracterizado por su virtud y por su sufrimiento, es de hecho una de las constantes del "populismo" discursivo de los republicanos en torno al fin de siglo (Torres Ballesteros, 1987, p. 171). En línea con la "demolatría" progresista (Castro Alfín, 1987, p. 201), Ángeles López de Ayala presenta al pueblo como una víctima de martirios y persecuciones, de la explotación de los "zánganos derrochadores de fortunas amasadas con el sudor y las lágrimas del paria" (López de Ayala, 1917, 15 de diciembre), al mismo tiempo que insiste en la bondad, la bizarría y la heroicidad de esa masa popular liberal y librepensadora, "de soldados y apóstoles" 'López de Ayala, 1898, 11 de mayo), ansiosa de redimirse, convencida de sus ideales y dispuesta a emprender el camino de la revolución social.

Al traspasar el nuevo siglo, el compromiso inicial de la autora seguía intacto, tal como revelan los artículos de tinte personal y también los de contenido social publicados en El Gladiador. Y es que en ese abrupto camino hacia la justicia y la igualdad que comporta la subversión de los poderes establecidos y la emancipación popular, López de Ayala avistaba en aquellos años una intermediación de singular valor: la de la intelectualidad republicana y librepensadora. Tal como señala en 1907 en "Menos política y más emancipación” (López de Ayala, 1907, 29 de junio), los librepensadores son depositarios de una gran responsabilidad, la de unir sus esfuerzos para canalizar las aspiraciones del pueblo, luchar por las reformas políticas y "dar sabia [sic] abundante y robustecedora" al "cuerpo social"; para ello, deben sacrificar sus intereses políticos inmediatos en la defensa de un ideal más noble: la emancipación de las conciencias. Un mes más tarde, y en las mismas páginas de El Gladiador, la autora muestra su impaciencia ante la inacción de republicanos y librepensadores, incapaces en más de tres décadas -desde la Primera República- de poner fin a las injusticias sociales y las "maldades restauradoras". Propone en consecuencia la articulación conjunta de esas dos "falanges", proletariado y cuerpo político demócrata, las cuales, aun habiendo estado históricamente separadas por las artimañas de los poderes establecidos, deben superar sus respectivos temores y aprender a marchar unidas en el camino hacia un porvenir más igualitario (López de Ayala, 1907, 13 de julio).

Sin embargo, conforme los años avanzan y los desequilibrios sociales no se resuelven, la mirada crítica de la autora va ampliando su foco de interés. En la segunda década del siglo, la denuncia a las fuerzas restauradoras y a los colaboradores de la reacción va acompañada de las agrias censuras a la perversión o a la relajación de los ideales librepensadores en el bando demócrata, al que acusa de sostener un discurso hueco, sin aspiraciones de cambio real ni repercusiones en la acción directa (López de Ayala, 1914, 7 de noviembre).

En esos años, la brecha que la separa de los canales oficiales del librepensamiento se va haciendo especialmente notoria en uno de los campos de batalla más espinosos del asunto de la "redención" social: la igualdad de los sexos. La lucha por la redención de las clases explotadas era, en el ideario de López de Ayala, indesligable de la contienda feminista, al estar relegadas las mujeres, por el mero hecho de serlo, al escalón más bajo de la jerarquía social. En ellas, sometidas por los hombres de todas las clases sociales y de todos los ámbitos, hallaba López de Ayala a las víctimas más propiciatorias del injusto sistema de castas, uniendo la esclavitud socio-familiar a la jurídica, la política, la económica y la científica.

Cierto es que el compromiso de López de Ayala con la equidad entre los sexos, "germen sagrado que radica en la humana inteligencia" (López de Ayala, 1898, 30 de junio), vino siempre indisolublemente ligado al impulso del asociacionismo femenino, a sabiendas de que la unión de las mujeres era requisito imprescindible para impulsar su emancipación. Pero también es verdad que el sustento de los intelectuales librepensadores se trasluce en sus artículos como un requisito imprescindible para el cumplimiento de las aspiraciones femeninas. Desde sus primeros años en Barcelona venía López de Ayala colaborando estrechamente con aquellos librepensadores masones que, auxiliados por el laicismo, la ciencia positiva y la sociología, habían consolidado el ya citado "feminismo de hombres” (Sánchez i Ferré, 2006, p. 119), paralelo al de las mujeres y centrado tanto en combatir a la Iglesia -que consideraban la más terrible enemiga de la emancipación de la conciencia femeninacomo en convencer a sus colegas de la conveniencia de aliarse con ellas en la lucha por el progreso "sin alterar ni un ápice la estructura familiar" (Sánchez i Ferré, 2006, p. 119). Por esta razón, además de invitar a las mujeres a abrazar el proyecto de la razón y del librepensamiento, López de Ayala propone en repetidas ocasiones que tal profesión de sororidad quede reforzada por la colaboración de los hombres "dignos y cultos" (López de Ayala, 1915, 18 de septiembre), a quienes anima a favorecer la autonomía femenina en favor del perfeccionamiento humano (López de Ayala, 1907, 16 de noviembre). 
En este sentido, las pretensiones emancipatorias de López de Ayala, en consonancia con las líneas de los feminismos vigentes, asumen las bases del reparto institucional de funciones sexuales en el seno de la intimidad del hogar, como soporte y pretexto de la evidente transgresión que implica la exigencia de la igualdad intelectual y jurídica de las mujeres, así como la de su imprescindible proyección pública. Pero al igual que le ocurre con el asunto de la reivindicación social, la impaciencia primero y la indignación más tarde inundan, a la vista de los escasos progresos de la causa y de la tibia implicación de sus colegas librepensadores, las reflexiones más tardías de López de Ayala sobre el particular. La existencia de castas intelectuales por razón de sexo es uno de los asuntos que aborda con mayor enconamiento, denunciando los prejuicios masculinos contra las mujeres que destacan en el uso de la razón y, muy especialmente, contra las que se atreven a tomar la pluma. Esta prevención hacia las mujeres ilustradas la experimentan, según señala la autora, hasta los hombres más justos y probos por inercia de la intelectualidad española (López de Ayala, 1916, 2 de diciembre) ${ }^{8}$. Por ello, en los artículos publicados en El Gladiador del Librepensamiento, ya durante la segunda década del siglo, se muestra especialmente exigente con los que postulan un feminismo de imposturas y frases hechas, y los exhorta a renunciar a unas superioridades intelectuales "harto discutibles" para auspiciar la emancipación de las mujeres (Arkinstall, 2014b, p. 67) y "romper las cadenas que las aprisionan al negro muro de su nulidad presente" (López de Ayala, 1915, 18 de septiembre).

La modificación en sus expectativas sobre el apoyo incondicional de los círculos librepensadores se traduce en un tono cada vez más reivindicativo y desafiante hacia aquellos: “¿Dejaréis que la semilla de la redención femenina se pierda a penas [sic] germinada? iSobre vosotros caerá el baldón y la ignominia a que os habréis hecho acreedores por vuestra insignificancia!" (López de Ayala, 1915, 18 de septiembre). Se intensifican también las reclamaciones en la equiparación de "derechos y deberes" políticos, que van tomando, en el camino común hacia la configuración de una ciudadanía femenina en clave democrática (Sanfeliu, 2008, p. 66), una clara deriva sufragista (López de Ayala, 1918, 18 de octubre), y adquiriendo una urgencia provocadora (López de Ayala, 1918, 18 de mayo) e incluso veladamente amenazadora (López de Ayala, 1919, 17 de diciembre).

En definitiva, la lectura cronológica de sus artículos nos permite percibir con claridad cómo la ilusión inicial con la que auspiciaba la positiva incidencia de la actuación de la progresía intelectual en "el problema femenino", va cediendo paso a los reproches y a las fisuras con la posición de la ortodoxia republicana y librepensadora en esta cuestión. Si en sus inicios el compromiso de la escritora con la emancipación femenina y con los valores librepensadores se articulaba conjuntamente, entendiendo ambos como vías complementarias de un mismo proyecto social, con el paso del tiempo la urgencia de la primera y la ausencia de soluciones de los segundos la van conduciendo hacia un discurso cada vez más transgresor.

\section{CONCLUSIONES}

A partir de aquel famoso pacto suscrito antes del cambio de siglo, López de Ayala y Acuña transitaron líneas ideológicas paralelas en su actividad periodística, tanto en su compromiso con la defensa de los ideales esbozados entonces como en la transgresión que supuso el mantener e implementar ese acuerdo de juventud a lo largo de las décadas; líneas paralelas, coincidentes en sus metas y en sus ejes fundamentales, pero con matices diferentes en su desarrollo concreto.

Acuña, por su parte, proclamaba en 1915 que la "nueva era de razón y virtud" (Bolado, 2007-2009, vol. IV, p. 344) habría de cimentarse sobre los desheredados y oprimidos, pero sus textos trasmiten también la aguda conciencia de que ese visionario esfuerzo constructor era tan necesario como limitado, pues tendrían que sucederse muchas generaciones hasta que fuera posible recoger los frutos de la lucha presente: "Así es como tenemos que empuñar nuestra bandera; $\sin$ la esperanza limitada a nuestro corto existir terrenal [...] no venceremos, pero habremos servido a la razón" (Bolado, 2007-2009, vol. IV, pp. 157-158). Si la transgresión constituye una ruptura con las reglas y una acción de traspasar límites, es llamativo el vigor con que el discurso contestatario de Acuña evitó alinearse con partidos políticos o ideologías de vocación hegemónica para preservar un marco flexible que asegurase su absoluta independencia intelectual. Esta actitud, que ha contribuido a su catalogación como escritora iconoclasta e inclasificable y como librepensadora en el sentido más literal del término, la llevó a buscar el aislamiento, evitar la vida pública y rechazar el repertorio político al uso: "ni soy socialista, ni anarquista, ni republicana, en el sentido redilesco de estas adjetivaciones; nada que huela a dogma, imposición y enchiqueramiento" (Bolado, 2007-2009, vol. IV, p. 433). Su posición heterodoxa da cuenta de la singularidad de esta intelectual que eligió establecerse en los márgenes para articular su desacato con un discurso alternativo que proponía una transformación radical del orden y plantaba semillas para un futuro que sabía que no habría de ver. 
Ángeles López de Ayala, sin embargo, se sitúa dentro de un marco ideológico muy preciso, el del republicanismo, y aunque no se alinea con ningún partido político concreto ("somos partidarios de la idea [...] somos republicanos de la república", López de Ayala, 1906, 15 de agosto), simpatiza con la revolución y lo hace desde la implicación absoluta en la vida pública, desde la dirección de los periódicos, los mítines, las conferencias, las escuelas laicas, etc. Su actividad es, de hecho, tan plural como inagotable. Ese compromiso que mantiene desde el principio se va radicalizando y adquiriendo progresivamente cotas de transgresión más amplias: la argumentación va cediendo paso a la exigencia, las razones derivan en una reclamación sin tregua de la justicia natural. El compromiso inicial, que para realizarse requiere no solo de la auctoritas sino de una igualdad efectiva y de una potestas que las barreras infranqueables de género no permiten asumir, se le revela insuficiente y requiere de una transgresión doble: la consustancial al desarrollo de un discurso igualitario, laicista y emancipista en la escritura femenina, y la que emana del desafío a las propias bases librepensadoras.

Pero más allá de esa mirada personal con la que cada una de estas dos escritoras y amigas librepensadoras materializa, desde un marco ideológico general común, ese pacto juvenil de compromiso y transgresión, el activismo y los textos de Ángeles López de Ayala y de Rosario de Acuña documentan también la existencia de redes de cooperación, de sororidad y solidaridad entre mujeres, de acción colectiva e intelectual (Moral Vargas, 2007, pp. 543-545) al amparo de ideales republicanos, librepensadores, feministas y masónicos. Ambas compartieron una voluntad siempre crítica hacia las jerarquías o castas de toda índole (sacerdotales, políticas, monárquicas, clasistas y patriarcales), considerándolas instrumentos de opresión y tiranía contra el pueblo, así como los principales obstáculos para la instauración de una sociedad igualitaria. En sintonía con esa conciencia de pueblo oprimido, ambas perseveraron en la defensa de la emancipación y la consecución de derechos para las mujeres, denunciando la desigualdad promovida desde instancias del poder que impedían un avance real y reforzaban la posición de aquellas como ciudadanas de segunda categoría. El trabajo intelectual de estas escritoras ilustra así el modo en que cumplieron fielmente su pacto, barajando estrategias de compromiso y transgresión para persistir en un esfuerzo intelectual, político y feminista que llevaron a cabo durante décadas "por la pluma, por el mitin y por la conferencia” (López de Ayala, 1920, 1 de mayo).

\section{AGRADECIMIENTOS}

Este trabajo conjunto se ha realizado en el marco del proyecto de investigación Género, compromiso y transgresión en España, 1890-2016 (Ministerio de Economía y Competitividad, FEM2016-76675-P).

\section{NOTAS}

[1] Pese a que, como se explica a continuación, ambas coincidieran y se conocieran en Madrid en fechas tempranas (década de 1880), la sevillana Ángeles López de Ayala se trasladó a Barcelona en 1888 , ciudad en la que murió en el año veintiséis. Por su parte, Rosario de Acuña, oriunda de la capital, se mudó a finales de 1909 o principios de 1910 a Gijón, donde estableció su residencia hasta su fallecimiento en 1923.

[2] Mejías-Alonso y Arias Coello han destacado que el siglo XIX es "por excelencia, el siglo de la prensa escrita” (1998, p. 241). En ese momento la actividad de la mujer escritora se profesionaliza y muchas autoras colaboran en la prensa periódica. Los periódicos progresistas del último tercio del XIX, favorecidos por sucesivos decretos avalando la libertad de prensa, contribuyeron enormemente al debate público (Díaz-Marcos, 2014) y el perio- dismo se convirtió en una industria que mantuvo su espíritu de combate como "arma de pelea" (Roch, 1923, p. 258). La antología de Íñigo Sánchez Llama constituye uno de los textos de referencia para abordar la inestimable aportación de las autoras a la prensa isabelina. La revista Arbor ha editado un magnífico volumen monográfico sobre Mujer y periodismo en el siglo XIX (Palomo, 2014).

[3] Su autoexilio de cuatro años en Portugal para evitar la cárcel -se la procesó en rebeldía- respondió a la polémica provocada por la publicación en 1911 de su artículo "La jarca de la universidad", que muchos consideraron una afrenta a la nación y a la masculinidad. Elena Hernández Sandoica ofrece un magnífico estudio de esta desafortunada anécdota periodística y una interpretación del escándalo que provocó su texto (2012, pp. 95-169).
[4] Esta publicación en español estaba editada y dirigida por el librepensador gallego Ramón Verea García.

[5] Varios hechos destacables tuvieron lugar el año anterior. En enero de 1883 fallece su padre y a partir de abril Acuña vive sola en Pinto separada de hecho de su marido, que era militar y fue trasladado entonces a Badajoz. Algunas fuentes sugieren que se negó a aceptar una infidelidad del esposo y desde entonces llevaron vidas separadas (Bolado, 2007-2009, vol. I, pp. 82-83). Ese mismo año descubre Las Dominicales del Libre Pensamiento y se hace ávida lectora del semanario. Su nueva condición de mujer "libre" pudo haber sido determinante en su trayectoria intelectual y en la orientación de sus reflexiones en materia de religión, feminismo y asuntos sociales a partir de ese momento. 
[6] Este artículo compartía página con otro titulado "El pueblo debe imponerse" que establecía que "el republicanismo vital, ha de ser rebelde, de ruda y acentuada oposición al Gobierno [...]. Nada de combinaciones ni pactos; guerra sin cuartel [...]. Pueblo debes imponer. Tu reivindicación es tu fuerza, es tu labor, es tu instrucción". Estas ideas permiten establecer una noción del "pueblo" como entidad masculina de forma que la "mujer del pueblo" resulta víctima de una tiranía encadenada: explotada como miembro del "pueblo" y oprimida como mujer, incluso por el sector revolucionario que ignora las reclamaciones y derechos de sus conciudadanas.
[7] López de Ayala publicó allí decenas de artículos entre mayo de 1891 y junio de 1902, así como en su continuador, Las Dominicales, entre agosto de 1904 y junio de 1906. (Arkinstall, 2014a, p. 64). El catálogo de sus artículos se encuentra en la tesis doctoral de María Victoria Clemente Palacios sobre Ángeles López de Ayala (2015, pp. 307-309).

[8] Aunque en líneas generales los librepensadores coincidían en prescribir el laicismo y la educación de las mujeres para un mejor cumplimiento de sus funciones en el ámbito del "cuidado" familiar, entre ellos florecieron escasas iniciativas efectivas para mejorar la situación de aquellas, e incluso persistieron las actitudes antifeministas y misóginas, apoyadas en el reconocimiento de ciertas características psico-biológicas del género femenino (Salomón Chéliz, 2005, pp. 105 y 112). M.a Dolores Ramos (2005) señala cómo, pese a que muchos librepensadores soñaban con una nueva "Eva" secularizada que impulsara la libertad de conciencia y el progreso, e incluso tendían a contraer matrimonio con mujeres de ideas avanzadas, la realidad social e intrafamiliar era bien diferente. Esta lucha, más civil y social que estrictamente política, llevó a algunas republicanas, como es el caso de López de Ayala, a reprochar y denunciar la inacción -o la hipocresía- de los hombres progresistas en el asunto de la emancipación femenina.

\section{BIBLIOGRAFÍA}

Acuña, R. (1920, 17 de abril). Carta Abierta. El Motín, p. 1.

Álvarez Junco, J. (1990). El Emperador del paralelo. Lerroux y la demagogia populista. Madrid: Alianza.

Álvarez Junco, J. (1993). Los intelectuales: anticlericalismo y republicanismo. En García Delgado, J. L. (comp.). Los orígenes culturales de la II República. Madrid: Siglo XXI, pp. 101-126.

Álvarez Junco, J. (1994). Los amantes de la libertad: la cultura republicana española a principios del siglo XX. En Townson, N. (ed.). El republicanismo en España (1830-1977). Madrid: Alianza Editorial, pp. 262-292.

Arkinstall, C. (2014a). Spanish Female Writers and the Freethinking Press. 1879-1926. University of Toronto Press. https://doi. org/10.3138/9781442668836

Arkinstall, C. (2014b). An Overlooked Chapter in Spanish Feminist Histories: Ángeles López de Ayala's El Gladiador del Librepensamiento (1914-1920). Revista de Estudios Hispánicos, 48 (1), pp. 49-74. https://doi.org/10.1353/rvs.2014.0010

Bifani-Richard, P. (2004). Género y sus transgresiones: ¿contra la norma o contra sí misma? Revista de Estudios de Género, La Ventana, 2 (20), pp. 7-52.

Bolado, J. (ed.) (2007-2009). Rosario de Acuña. Obras reunidas. Oviedo: KRK.

Castro Alfín, D. (1987). Jacobinos y populistas. El republicanismo español a mediados del siglo XIX. En Álvarez Junco, J. (comp.). Populismo, caudillaje y discurso demagógico. Madrid: Siglo XXI, pp. 181-218.
Cejador y Frauca, J. (1918). Historia de la lengua y literatura castellana (vol. 9). Madrid: Tipografía de la Revista de Archivos y Bibliotecas.

Clemente Palacios, M. V. (2015). Ángeles López de Ayala (1858-1926): icono del librepensamiento en la España de entre siglos. [Tesis Doctoral inédita]. Madrid: Universidad Complutense de Madrid.

Díaz Marcos, A. M. (2014). Misiones del racionalismo: Rosario de Acuña en la prensa librepensadora. Arbor 190 (767), a134. https://doi.org/10.3989/ arbor.2014.767n3005

Domingo Soler, A. (1976). Sus más hermosos escritos. Buenos Aires: Kier.

Gómez Molleda, M. D. (1996). Inteligencia, poder y secularización en la España contemporánea. En Álvarez Lázaro, P. Librepensamiento y secularización en la España contemporánea. Madrid: Universidad Pontifica de Comillas, pp. 297-320.

Hernández Sandoica, E. (2012). Espacio público y espacio privado. Madrid: Abada.

Lacalzada de Mateo, M. J. (2006). Mujeres en masonería: antecedentes históricos entre las luces y las sombres (18681938), Premià de Mar: Clavell.

López de Ayala, Á. (1894, 7 de diciembre). De enhorabuena. Las Dominicales del Libre Pensamiento, p. 2.

López de Ayala, Á. (1895, 22 de febrero). EI banquete de Rubí. Las Dominicales del Libre Pensamiento, p. 2.
López de Ayala, Á. (1898, 11 de mayo). Un esfuerzo y concluido. Las Dominicales del Libre Pensamiento, p. 1.

López de Ayala, Á. (1898, 30 de junio). La Sociedad Progresiva Femenina. Las Dominicales del Libre Pensamiento, p. 2.

López de Ayala, A. (1901, 24 de mayo). Carta de Doña Ángeles. Las Dominicales del Libre Pensamiento, p. 2.

López de Ayala, Á. (1903, 13 de marzo). ii Eruptan de hartos!!! Las Dominicales del Libre Pensamiento, p. 4.

López de Ayala, Á. (1906, 15 de agosto). Lo que somos. El Gladiador. Órgano de la Sociedad Progresiva Femenina, p. 1.

López de Ayala, Á. (1907, 29 de junio). ¡Menos política y más emancipación! El Gladiador. Órgano de la Sociedad Progresiva Femenina, pp. 1-2.

López de Ayala, Á. (1907, 13 de julio). ¿Hasta cuándo? El Gladiador. Órgano de la Sociedad Progresiva Femenina, pp. 1-2.

López de Ayala, Á. (1907, 12 de octubre). Como rocas. El Gladiador. Órgano de la Sociedad Progresiva Femenina, pp. 1-2.

López de Ayala, Á. (1907, 16 de noviembre). A las Mujeres. El Gladiador. Órgano de la Sociedad Progresiva Femenina, pp. 1-2.

López de Ayala, Á. (1908, 1 de febrero). Es inútil. El Gladiador. Órgano de la Sociedad Progresiva Femenina, p. 1.

López de Ayala, Á. (1914, 21 de junio). ¿Qué no existe? El Gladiador del Librepensamiento, p. 1. 
López de Ayala, Á. (1914, 7 de noviembre). ¿La Solución?... El Gladiador del Librepensamiento, p. 1

López de Ayala, Á. (1915, 17 de abril). La ansiada ley se escribirá con sangre. El Gladiador del Librepensamiento, p. 1.

López de Ayala, Á. (1915, 18 de septiembre). Aún no hay que cantar victoria. El Gladiador del Librepensamiento, p. 1

López de Ayala, Á. (1915, 4 de diciembre). ¡Son ellos! El Gladiador del Librepensamiento, p. 1.

López de Ayala, Á. (1916, 3 de junio). Presentación oficial del Comité de la Federación de Librepensadores. El Gladiador del Librepensamiento, p.1.

López de Ayala, Á. (1916, 16 de julio). Las huelgas actuales. El Gladiador del Librepensamiento, p.1.

López de Ayala, Á. (1916, 2 de diciembre). No abandonemos el problema femenino. EI Gladiador del Librepensamiento, p. 1.

López de Ayala, Á. (1917, 19 de mayo). A nuestros lectores. El Gladiador del Librepensamiento, p. 1.

López de Ayala, Á. (1917, 15 de diciembre). ¡Qué invierno! El Gladiador del Librepensamiento, p. 1.

López de Ayala, Á. (1918, 18 de mayo). ¡Llegó la hora! El Gladiador del Librepensamiento, p.1.

López de Ayala, Á. (1918, 18 de octubre). ¿Más privilegios? El Gladiador del Librepensamiento, p. 1

López de Ayala, Á. (1919, 17 de diciembre). La mensajera. El Gladiador del Librepensamiento, p. 1.

López de Ayala, Á. (1920, 1 de mayo). Señora doña Rosario de Acuña. El Motín, p. 1.

López de Ayala, Á. (1923, 19 de mayo). El mejor florón. El Motín, p. 2.

Madrid (1888, 4 de noviembre). El País: Diario republicano progresista, p. 1.

Mejías Alonso, A. y Arias Coello, A. (1998) La prensa del siglo XIX como medio de difusión de la literatura Hispanoamericana. Revista general de información y documentación, 8 (2), pp. 241-257.

Moral Vargas, M. del (2007). Acción colectiva femenina republicana: las "Damas Rojas» de Madrid (1909-1911), una breve experiencia política. Hispania LXVII (226), pp. 541-566. https://doi. org/10.3989/hispania.2007.v67.i226.53

Mosén Pedro (1917, 3 de febrero). Sobre lo mismo. El Ideal: Órgano de las Juventudes Republicanas Revolucionarias de los distritos de Tolosa y Roquetas, $\mathrm{pp}$. 1-2. Disponible en https://prensahistorica.mcu.es/es/publicaciones/numeros_por_mes.do?idPublicacion $=1484 \&$ anyo $=1917$

Ortiz Albear, N. (2005). Las mujeres en la masonería. Málaga: Universidad de Málaga.

Palomo, P. (coord.) (2014). Mujer y periodismo en el siglo XIX. Las Pioneras. Arbor, 190 (767), Disponible en: http://arbor. revistas.csic.es/index.php/arbor/issue/ view/152/showToc

París y Zejín, L. (1889). Gente nueva. Crítica inductiva. Madrid: Imprenta popular.

Presmanes García, R. E. (2012). La masonería femenina en España. Dos siglos de historia por la igualdad. Madrid: Los Libros de la Catarata.

Ramos Palomo, M. D. (1999). Mujer, asociacionismo y sociabilidad en la coyuntura de 1898. Las afinidades con el fin de siglo europeo. En Sánchez Sánchez, I. y Villena Espinosa, R. (coords.). Sociabilidad fin de siglo. Espacios asociativos en torno a 1898. Cuenca: Ediciones de la Universidad de Castilla-La Mancha, pp. 73-99.

Ramos Palomo, M. D. (2002). La cultura societaria del feminismo librepensador (1895-1918). En Bussy Genevois, D. (ed.). Les espagnoles dans l'histoire. Une sociabilité démocratique (XIXe-XXe siècles). Saint-Denis: Presses Universitaires de Vincennes, pp. 103-124.

Ramos Palomo, M. D. (2005). La República de las librepensadoras (1890-1914): laicismo, emancipismo, anticlericalismo. Ayer, 60 (4), pp. 45-74.

Ramos Palomo, M. D. (2010). Las primeras modernas. Secularización, activismo político y feminismo en la prensa republicana: Los Gladiadores (1906-1919). Historia Social, 67, pp. 93-112.

Ramos Palomo, M. D. (2011). Feminismo laicista: voces de autoridad, mediaciones y genealogías en el marco cultural del modernismo. En Aguado, A. y Ortega, T. M. (eds.), Feminismos y antifeminismos: culturas políticas e identidades de géne- ro en la España del siglo XX. Valencia: Universidad de Valencia, pp. 21-44.

Roch, L. (1923). 75 años de periodismo con motivo de las bodas de diamante de "La época". Madrid: Ramona Velasco.

Salomón Chéliz, M. P. (2005). Las mujeres en la cultura política republicana: religión y anticlericalismo. Historia Social, 53, pp. 103-118.

Salomón Chéliz, M. P. (2011). Devotas mojigatas, fanáticas y libidinosas: anticlericalismo y feminismo en el discurso republicano a finales del siglo XIX. En Aguado, A. y Ortega, T. M. (eds.), Feminismos y antifeminismos: culturas políticas e identidades de género en la España del siglo XX. Valencia: Universidad de Valencia, pp. 71-98.

Sánchez i Ferré, P. (2006). La masonería, el librepensamiento y los orígenes del feminismo en Cataluña. 1870-1920. Bulletin d'Histoire Contemporaine de l'Espagne, 32, pp. 117-142.

Sánchez Llama, Í. (2001). Antología de la prensa periódica isabelina. Cádiz: Universidad de Cádiz.

Sanfeliu, L. (2008). Del laicismo al sufragismo. Marcos conceptuales y estrategias de actuación del feminismo republicano entre los siglos XIX y XX. Pasado y Memoria, 7, pp. 59-78. https://doi. org/10.14198/PASADO2008.7.04

Suárez Cortina, M. (2000). El gorro frigio. Liberalismo, democracia y republicanismo en la Restauración. Madrid: Biblioteca Nueva.

Torres Ballesteros, S. (1987). El populismo. Un concepto escurridizo. En Álvarez Junco, J. (comp.). Populismo, caudillaje y discurso demagógico. Madrid: Siglo XXI, pp. 159-180

Viveros Vigoya, M. (2016). La interseccionalidad: una aproximación situada a la dominación. Debate Feminista, 52, pp. 1-17. https://doi.org/10.1016/j. df.2016.09.005

Zavala, I. M. (2000). Modernidades sexualizadas: el corredor de las voces femeninas. En Escaja, T. (ed.). Delmira Agustini y el modernismo: nuevas propuestas de género. Rosario, Argentina: Beatriz Viterbo.

Zavala, I. M. (2004). La otra mirada del siglo XX: la mujer en la España contemporánea. Madrid: La esfera de los libros. 